\title{
Genetic diversity of indigenous catfish from Indonesia based on mitochondrial Cytochrome Oxidase Subunit II gene
}

\author{
VISTA BUDIARIATI ${ }^{1, \vartheta}$, TRINI SUSMIATI ${ }^{2}$, SITI MUNAWAROH ${ }^{3}$, \\ RACHMAWATI CAHYANINGTYAS ARIE PUTRI ${ }^{3}$, RINI WIDAYANTI ${ }^{2, \vartheta \varphi}$ \\ ${ }^{1}$ Faculty of Veterinary Medicine, Universitas Gadjah Mada. J1. Fauna No. 2, Karangmalang, Sleman 55281, Yogyakarta, Indonesia. \\ Tel.: +62- 274-6492088, 560862, Fax.: +62-274-560861, `email: vista.budiariati@ugm.ac.id \\ ${ }^{2}$ Department of Biochemistry, Faculty of Veterinary Medicine, Universitas Gadjah Mada. J1. Fauna No. 2, Karangmalang, Sleman 55281, Yogyakarta, \\ Indonesia. Tel.: +62- 274-6492088, 560862, Fax.: +62-274-560861, ^^email: rini_widayanti@ugm.ac.id \\ ${ }^{3}$ Veterinary Medicine Program, Faculty of Veterinary Medicine, Universitas Gadjah Mada. Jl. Fauna No. 2, Karangmalang, Sleman 55281, Yogyakarta, \\ Indonesia
}

Manuscript received: 10 December 2020. Revision accepted: 8 January 2021.

\begin{abstract}
Budiariati V, Susmiati T, Waroh S, Putri RCA, Widayanti R. 2021. Genetic diversity of indigenous catfish from Indonesia based on mitochondrial Cytochrome Oxidase Subunit II gene. Biodiversitas 22: 593-600. Catfish is one of the most demanding fish in Indonesia and served in a variety of traditional culinary. Due to their identical morphology and close relation between species in the order of Siluriformes, it is quite tricky to distinguish the species. This can be a threat to develop catfish production in Indonesia since there is a wide variety of catfish species in this mega biodiversity country. The study aimed to analyze the genetic diversity of Indonesian indigenous catfish especially those known as Baung fish by local people based on COII gene. The study also aimed to determine the phylogenetic relationship between the samples and compare them with the GenBank data. A total of 24 samples used in this study from 8 different rivers from 3 different islands and two samples were collected from coastal areas. The study results showed that there is genetic diversity of the Indonesian indigenous catfish based on COII gene. The sequences among 24 samples showed that from 691 nucleotides of COII gene, there were very subtle nucleotides differences of samples that originated from Bojonegoro, Magelang, and samples collected from Baru Beach, Yogyakarta. Based on COII amino acid sequences, 6 polymorphic amino acid sites were on-site number 64, 115, 123, 129,144 , and 165. The samples encoded LLB1 and LPB1 from Baru Beach, Yogyakarta, showed highest different amino acids in the six sites. Samples from the river of Central Java, Sumatra, and Kalimantan belonged to Bagridae family and consist of two different species Hemibagrus sp. and Mystus sp while samples from East Java belonged to Pangasiidae family. The Samples from coastal belonged to Ariidae family.
\end{abstract}

Keywords: Bagridae, cytochrome oxidase subunit II, Indonesian indigenous catfish, phylogenetic, Siluriformes

\section{INTRODUCTION}

Catfish is one of the most demanding fish in Indonesia and served in a variety of traditional Indonesian culinary delights. It also has high protein content and promising for being a good source of protein and other nutritional values (Kawiji et al. 2020; Mesomya et al. 2015). The fish are more adaptable and possess all the characteristics necessary for aquaculture including relatively high fecundity, ability for artificial spawning, adaptability to earthen ponds for culture, high tolerance to low dissolved oxygen, relatively high resistance against infectious diseases, and relatively high feed conversion efficiency (Jin et al. 2016). Catfish is one of the primary aquaculture species in the United States and its global importance is increasing in several countries in Asia including Indonesia (Liu 2008; Liu, 2011).

Catfish belong to the order of Siluriformes which is one of the largest orders of teleosts. Currently, 36 families and over 3,000 species are recognized, rendering catfishes among the most diverse vertebrate orders (approximately 1 in 10 actinopterygians or 1 in 20 vertebrates is a catfish) (Ferraris 2007; Kappas et al. 2016).

The fish's characteristics include whisker-like barbels, which are located on the nose, each side of the mouth, and on the chin, possess leading spines in their dorsal and pectoral fins (Arce et al. 2013; Armbruster, 2004). They are scaleless which is a characteristic that distinguishing them from most other teleost fish (Jin et al. 2016). However, due to their identical morphology and close relation between species in the order of Siluriformes, it is quite tricky to distinguish the species of the catfish. This can be a threat to develop catfish production in Indonesia since there is a wide variety of catfish species in this mega biodiversity country. Moreover, local people in Indonesia tend to use the same term to identify this type of fish. Analysis of genetic diversity is a critical measure in population studies, including for catfish, because by hinting on the evolutionary history of a population, it reveals the current and future health of the population since low levels of genetic diversity causes inbreeding depression in the short run and reduced evolutionary potential in the long run (Buj et al. 2014; Kirk and Freeland 2011).

Previous studies reported that indigenous catfish of Indonesia classified into Hemibagrus nemurus, which belong to Bagridae family, but there are some species that allocated in the Pangasiidae family based on cytochrome oxidase subunit III and species from Papua that belong to Ariidae family based on cytochrome B gene (Syaifudin et 
al. 2017; Widayanti et al. 2019; Megarani et al. 2020). Genetic analysis itself recently highlighted related to the possibility for applications in fishery genetics (Kochzius 2009). The aims of this study was to analyze the genetic diversity of indigenous catfish from Indonesia based on mitochondrial cytochrome oxidase subunit II (COII) gene especially those known as Baung fish by the local people. The study also aimed to determine the phylogenetic relationship between the sample of indigenous catfish from Indonesia and compare them with the available sequence from the GenBank to develop DNA barcoding of catfish from different regions of Indonesia from the mitochondrial DNA sequences.

\section{MATERIALS AND METHODS}

\section{Sample collections}

A total of 24 samples from different regions of Indonesia known as Baung catfish for local people were collected and used as the samples of this study. The origin of the samples was from 8 different rivers from 3 different islands and two samples were collected from Baru Beach, Yogyakarta. The origin, number of samples as well as codes of the samples are presented in Table 1. Geographical map of sampling sites as shown in Figure 1. Each sample was taken individually from its habitat after being identified based on the morphologies. The samples used in this study were the tissues preserved in the RNA latter buffer (Qiagen) and then used for the total DNA isolation.

The DNA for the genetic analysis was extracted from the tissue biopsy $(30 \mathrm{mg})$. DNA Isolation Kit (Qiagen) was used for DNA extraction and purification. Extracted total

DNA was detected by electrophoresis method and stored at $-20^{\circ} \mathrm{C}$ until further examination. Amplification of the targeted DNA fragments was done by polymerase chain reaction (PCR) method. The pair primer of COII gene was designed with Primer3 output program (http://wwwgenome.wi.mit.edu/cgi.bin/primr3.cgi/results_f rom-primer3) based on genetic sequence data of Hemibagrus nemurus (Access Number KJ573466.1) and Mystus vittatus (Access Number KX177968.1). The primer sequences for DNA amplification were Baung_COIIF 5' CCGCTCTGTCACTTTCTTTT 3' and Baung_COIIR 5' GCTCATTTGTGTCCTCCTTT 3' with the melting temperature of $53,1^{\circ} \mathrm{C}$ and $53^{\circ} \mathrm{C}$. Amplification of the DNA was done in this condition: predenaturation 2 minutes at $94^{\circ} \mathrm{C}$; denaturation 30 seconds at $94^{\circ} \mathrm{C}$; annealing 45 seconds at $46^{\circ} \mathrm{C}$; elongation 1 minutes 30 seconds at $72^{\circ} \mathrm{C}(35$ cycles) and post-elongation 5 minutes at $72^{\circ} \mathrm{C}$.

Table 1. Indigenous catfish samples from Indonesia

\begin{tabular}{lcl}
\hline \multicolumn{1}{c}{ Origin } & $\begin{array}{c}\text { No. of } \\
\text { samples }\end{array}$ & Sample codes \\
\hline $\begin{array}{l}\text { Martapura River, Banjarmasin, South } \\
\text { Kalimantan }\end{array}$ & 3 & BJ1; BJ2; BJ3 \\
$\begin{array}{l}\text { Bengawan Solo River, Bojonegoro, } \\
\text { East Java }\end{array}$ & 3 & BO1; BO2; BO3 \\
$\begin{array}{l}\text { Elo River, Magelang, Central Java } \\
\text { Kapuas River, Sintang, West }\end{array}$ & 2 & EM1; EM2 \\
Kalimantan & 2 & KS1; KS2 \\
Kampar River, Pekanbaru, Riau & 3 & KR1; KR2; KR3 \\
$\begin{array}{l}\text { Mahakam River, Samarinda, East } \\
\text { Kalimantan }\end{array}$ & 3 & MS1; MS2; MS3 \\
$\begin{array}{l}\text { Musi River, Palembang, South Sumatra } \\
\text { Progo River, Magelang, Central Java }\end{array}$ & 3 & MP1; MP2; MP3 \\
Baru Beach, Yogyakarta & 2 & PM1; PM2; PM3 \\
\hline
\end{tabular}

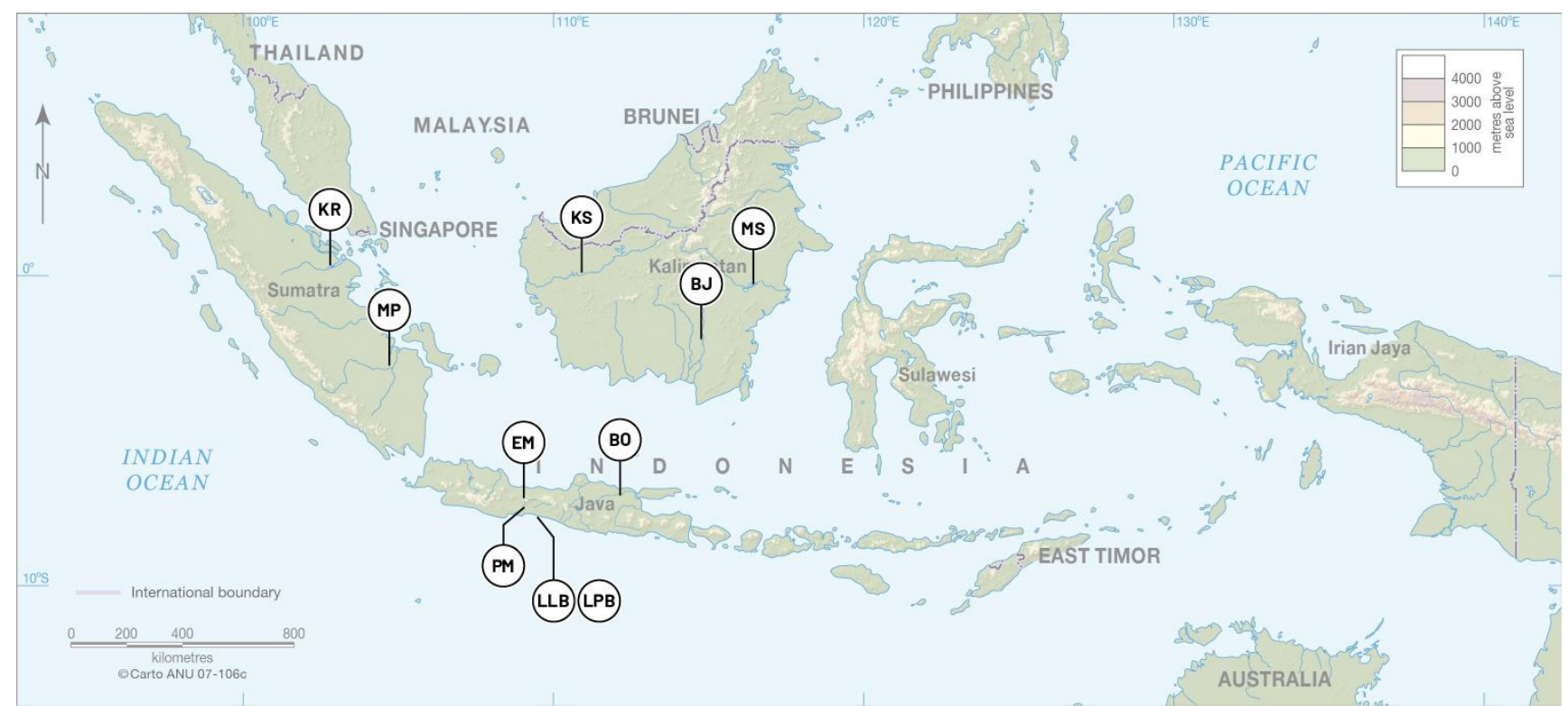

Figure 1. Geographical map of the sampling sites. BJ: Martapura River, Banjarmasin, South Kalimantan; BO: Bengawan Solo River, Bojonegoro, East Java; EM: Elo River, Magelang, Central Java; KS: Kapuas River, Sintang, West Kalimantan; KR: Kampar River, Pekanbaru, Riau, Sumatera; MS: Mahakam River, Samarinda, East Kalimantan; MP: Musi River, Palembang, South Sumatera; PM: Progo River Magelang, Central Java; LLB1, LPB1: Baru Beach, Yogyakarta, Indonesia 
Tabel 2. Amplicon product of mitochondrial DNA fragments (1242 bp) after being aligned with sequence data of Hemibagrus nemurus (NC_044863.1) from GenBank

\begin{tabular}{llc}
\hline $\begin{array}{c}\text { Nucleotide sequence } \\
\text { number (5'->3') }\end{array}$ & \multicolumn{1}{c}{$\begin{array}{c}\text { DNA } \\
\text { fragments }\end{array}$} & $\begin{array}{c}\text { Length of nucleotide } \\
\text { sequences }\end{array}$ \\
\hline $7063-7080$ & tRNASer & 18 \\
$7081-7084$ & intron & 4 \\
$7085-7157$ & tRNA Asp & 73 \\
$7158-7171$ & intron & 14 \\
$7172-7862^{*}$ & COII* & $691^{*}$ \\
$7863-7936$ & tRNALys & 74 \\
7937 & intron & 1 \\
$7938-8105$ & ATP8 & 168 \\
$8096-8304$ & ATP6 partial & 209 \\
\hline
\end{tabular}

Note: * targeted gene COII

The amplicon products after being aligned with sequence data of COII gene of Hemibagrus nemurus (NC_044863.1) from GenBank is 1242 bp at the site number 7063 to 8304 which amplifies several DNA fragments as shown in Table 2.

\section{Sequencing and phylogenetic analysis}

The sequencing of the amplicon products was done by $1^{\text {st }}$ Base Sequencing Int. (Singapore). The analysis of the sequences data was done using the MEGA program version $\mathrm{X}$ (Kumar et al. 2018). The sequences data were aligned with ClustalW followed by consensus editing and then compared to related sequence data from others catfishes recorded in the GenBank ((Hemibagrus nemurus (NC_044863.1); Mystus_vittatus (NC_032082.1); Mystus cavasius (NC_030187.1); Hemibagrus wyckioides (NC_024278.1); Hemibagrus guttatus (NC_023976.1); Mystus rhegma (NC_023223.1); Hemibagrus spilopterus (NC_023222.1); Liobagrus_marginatus (NC_022923.1); Pseudobagrus ondon (NC_022725.1); Liobagrus anguillicauda (NC_021602.1); Exostoma labiatum (NC_021601.1); Pseudobagrus truncates (NC_021395.1); Leiocassis crassilabris (NC_021394.1); Pseudobagrus brevicaudatus (NC_021393.1); Pseudobagrus ussuriensis (NC_020344.1); Hemibagrus macropterus (NC_019592.1); Glyptothorax fokiensis fokiensis (NC_018769.1); Pelteobagrus eupogon (NC_018768.1); Pelteobagrus fulvidraco (NC_015888.1); Pangasius_larnaudii (NC_015839.1); Pareutropius debauwi (NC_015837.1); Malapterurus electricus (NC_015833.1); Heteropneustes fossilis (NC_015827.1); Diplomystes nahuelbutaensis (NC_015823.1); Bunocephalus coracoideus (NC_015811.1); Auchenoglanis occidentalis (NC_015809.1); Synodontis schoutedeni (NC_015808.1); Silurus asotus (NC_015806.1); Pimelodus_pictus (NC_015797.1); $\quad$ Clarias $\quad$ sp. $\quad$ (NC_015749.1); Centromochlus perugiae (NC_015748.1); Pterygoplichthys disjunctivus (NC_015747.1); Amphilius sp. (NC_015746.1); Amblydoras gonzalezi (NC_015745.1); Pseudobagrus brevicorpus (NC_015625.1); Pelteobagrus nitidus (NC_014859.1); Leiocassis longirostris (NC_014586.1); Cranoglanis bouderius (NC_008280.1); Corydoras rabauti (NC_004698.1); Pseudobagrus tokiensis (NC_004697.1); Ictalurus punctatus (NC_003489.1); Arius arius
(NC_036673.1); Arius maculatus (NC_045222.1); Outgroup: Cyprinus carpio (NC_001606.1)).

The COII targeted gene (691 bp) from the samples then analyzed to determine the genetic diversity using Kimura 2-parameter method, with 1000 replicates of the bootstrap method. The phylogenetic analysis was performed using Neighbor-joining to depict the relationship between the species and clusters between the individuals.

\section{RESULTS AND DISCUSSION}

\section{Variation of nucleotides and amino acids sequences}

Catfish have been the focus of varied research for many years due to high economic value related to their protein and other nutritional values (Kwasek et al. 2020). Catfishes are classified in the order Siluriformes which currently had 36 families and over 3,000 species are recognized (Ferraris 2007; Kappas et al. 2016). There is wide distribution of catfishes in Indonesia. It can be found in the rivers of Java, Sumatera, Kalimantan, Sulawesi, and Papua Island. Local people have used the morphological features to identify this species although determination based on the morphology itself may cause identification confound $(\mathrm{Ng}$ and Kottelat 2013).

Previous studies reported that geographical aspects in Indonesian lands influenced the speciation of catfish and resulted in genetic diversity of catfishes based on cytochrome-B and cytochrome oxidase subunit II gene (Widayanti et al. 2019; Megarani et al. 2020). Based on the previous reports, phylogenetic analysis using the DNA sequences is needed to reveal accurate species identification and support the conservation program. Finding the most appropriate gene sequences to distinguish the differences between species is also definitely needed to develop DNA barcodes as an effective species identification approach. Therefore, the aims of the study was to determine the molecular characteristic and phylogenetic relationship of the Indonesian catfish especially the fish known as Baung fish by local people using cytochrome oxidase subunit II gene.

The analysis of the sequences among 24 samples of the indigenous samples known as Baung fish by local people showed that from 691 nucleotides from COII gene there were very subtle nucleotides differences of samples which originated from Bojonegoro (Bengawan Solo River), Magelang (Elo River), and samples which were collected from Baru Beach Yogyakarta as shown in Table 3. The nucleotide differences resulted in the variation of amino acids between 24 samples. There were 6 polymorphic amino acid sites which were on site number $64,115,123$, 129, 144, and 165. The samples encoded LLB1 and LPB1 from the Baru Beach showed highest different amino acids in that 6 six sites, followed by samples encoded BO1, BO2, BO3 which showed differences in 4 sites (amino acid site number 115, 123, 144, 165). The samples encoded EM1 and EM2 had 2 amino acid polymorphic site on site number 123 and 129. Meanwhile, the samples encoded $\mathrm{KR} 1, \mathrm{KS} 1$, and KS2 showed 1 difference of amino acid on site number 129 as shown in Table 4 . 
Table 4. Amino acid polymorphic site

\begin{tabular}{|c|c|c|c|c|c|c|}
\hline \multirow{4}{*}{ Sample } & \multicolumn{6}{|c|}{ Amino acid site } \\
\hline & & $\mathbf{1}$ & $\mathbf{1}$ & $\mathbf{1}$ & 1 & $\mathbf{1}$ \\
\hline & 6 & 1 & 2 & 2 & 4 & 6 \\
\hline & 4 & 5 & 3 & 9 & 4 & 5 \\
\hline BJ1 & V & $\mathrm{N}$ & V & A & $\mathrm{V}$ & $\mathrm{L}$ \\
\hline $\mathrm{BJ} 2$ & . & . & . & . & . & . \\
\hline $\mathrm{BJ} 3$ & . & & & . & & \\
\hline BO1 & . & D & I & . & I & V \\
\hline $\mathrm{BO} 2$ & . & D & I & . & I & V \\
\hline BO3 & . & D & I & & I & V \\
\hline EM1 & . & . & I & $\mathrm{N}$ & . & . \\
\hline EM2 & . & . & I & $\mathrm{N}$ & . & . \\
\hline KR1 & . & . & . & $\mathrm{T}$ & . & . \\
\hline KR2 & . & . & . & . & . & . \\
\hline KR3 & . & . & . & & . & . \\
\hline KS1 & . & . & . & $\mathrm{T}$ & . & . \\
\hline $\mathrm{KS} 2$ & & $\cdot$ & & $\mathrm{T}$ & & \\
\hline LLB1 & I & . & I & $\mathrm{S}$ & I & $\mathrm{V}$ \\
\hline LPB1 & I & . & I & $\mathrm{S}$ & I & $\mathrm{V}$ \\
\hline MP1 & . & . & . & . & . & . \\
\hline MP2 & . & . & . & . & . & . \\
\hline MP3 & . & . & . & . & . & . \\
\hline MS1 & . & . & . & . & . & . \\
\hline MS2 & . & . & . & . & . & . \\
\hline MS3 & . & . & . & . & . & . \\
\hline PM1 & . & . & . & . & . & . \\
\hline PM2 & . & . & . & . & . & . \\
\hline PM3 & . & & & & & \\
\hline
\end{tabular}

Note: The identity of the samples shown in Table 1. Identification with the first sequence is denoted by a dot (.)

In this research, samples from Bengawan Solo River, Bojonegoro, East Java and from Elo River, Magelang, Central Java had high number of nucleotides differences as well as the amino acid variation. These results supported the confirmation that the samples were different species based on cytochrome-B and cytochrome oxidase subunit III gene (Widayanti et al. 2019; Megarani et al. 2020) whereas samples from the Progo River, Magelang, Central Java were less different and closer to the samples from other rivers from the different islands. These results strengthen the hypothesis that distinguishes the species based on morphological features is not fully accurate so that geneticbased identification is needed.

Comparing the samples from rivers or streams in Kalimantan, Sumatera, and Java revealed that the differences between the nucleotides and amino acid variations between samples were relatively not significantly different. The results indicate closely relation between indigenous catfishes from different rivers in the regions of Indonesia. In this study, we also add samples from Baru Beach Yogyakarta which had morphological similarity with samples taken from the various rivers and had been known by the local people as Baung fish, one of the local terminology of catfish in Indonesia. The samples from the coastal were included based on the morphology characteristic and it is possible to found the fish since catfish are highly diverse and distributed worldwide and commonly found in inland or coastal waters of all continents (Jin et al. 2016). Unfortunately, those samples originated from the beach were different from other sample-based on COII sequence which implies that the samples were different species.
The results of amino acid polymorphic sites were in line with the nucleotide differences. Based on COII amino acid sequences, 6 polymorphic amino acid sites were on site number $64,115,123,129,144$, and 165 . The most different sample which are the samples encoded LLB1 and LPB1 showed highest different amino acids in the six sites of amino acid polymorphic sites followed by samples BO1, $\mathrm{BO} 2, \mathrm{BO} 3$ (4 sites of amino acids differences), samples EM1 and EM2 (4 sites of amino acids differences) and samples KR1, KS1, and KS2 which had 1 differences of amino acids.

\section{Genetic distances between samples of indigenous catfish from different regions of Indonesia}

The differences of nucleotides that influenced the amino acid compositions also related to the genetic distance between species. The analysis of the genetic distance between the samples based on COII gene using Kimura 2-parameter method showed that samples encoded BJ1, BJ2, BJ3, MP1, MP2, MP3, KR2, MS1, MS2, MS3, PM1, PM2, PM3, KR3, KR1, KS1, KS2 were closer than those samples encoded BO1, BO2, BO3, EM1, EM2, LLB1, LPB1 which had higher score of genetic distance compared to other samples. This indicates genetic diversity between samples from different regions and also between individuals as shown in Table 5. The confirmation of the results was done by phylogenetic analysis to clarify the genetic diversity of the samples and determine the phylogenetic relationship with other species in the order of Siluriformes.

\section{Phylogenetic relationships between Indonesian catfish and other catfish species}

Order Siluriformes is one of the largest order of teleost which included not less than 4100 species, and representing approximately $12 \%$ of all teleosts and $6.3 \%$ of all vertebrates (Wilson and Reeder, 2005). It is reported that the order currently had 36 families and over 3,000 species are recognized (Ferraris 2007). The family of the order at least includes Amblycipitidae, Amphiliidae, Aspredinidae, Auchenipteridae, Bagridae, Callichtyidae, Clariidae, Cranoglanidididae, Diplomystidae, Doradidae, Heteropneustidae, Ictaluridae, Loricariidae, Malapteruridae, Mochokidae, Pangasiidae, Pimelodidae, Schilbeidae, Siluridae, and Sisoridae (Kappas et al. 2016). We used representatives of each family to compare the samples and other species from GenBank data and build the phylogenetic tree based on nucleotide and amino acid sequence. The comparative species are listed in the material and methods section.

The phylogenetic analysis was done to identify the taxon phenogram of the samples and the phylogenetic relationship of the Indonesian catfish samples and other related species. The analysis was done by constructing the phylogenetic tree using the NJ method. The phylogenetic tree between the samples and other species taken from GenBank shown in Figure 2. Figure 2 shows that the Indonesian catfish were separated into four clades or monophyletic groups, in conjunction with the other catfish species around the world. First, Indonesian catfish samples 
PM1, PM2, PM3, KR1, BJ1, BJ2, BJ3, KR2, MP1, MP2, MP3, MS1, MS2, MS3 and KS2, KR1, KS1 were clustered with Hemibagrus nemurus (NC_044863.1) and Hemibagrus wyckioides (NC_024278.1). Samples EM1 and EM2 were clustered with Mystus vittatus (NC_032082.1) and Mystus cavasius (NC_030187.1).
Furthermore, samples LLB1 and LPB1 were in the same groups with Silurus asotus (NC_015806.1); Bunocephalus coracoideus (NC_015811.1); Centromochlus perugiae (NC_015748.1). Samples BO1, BO2, BO3 were together with Pangasius larnaudii (NC_015839.1).

Table 3. Nucleotides differences of indigenous catfish from different regions of Indonesia

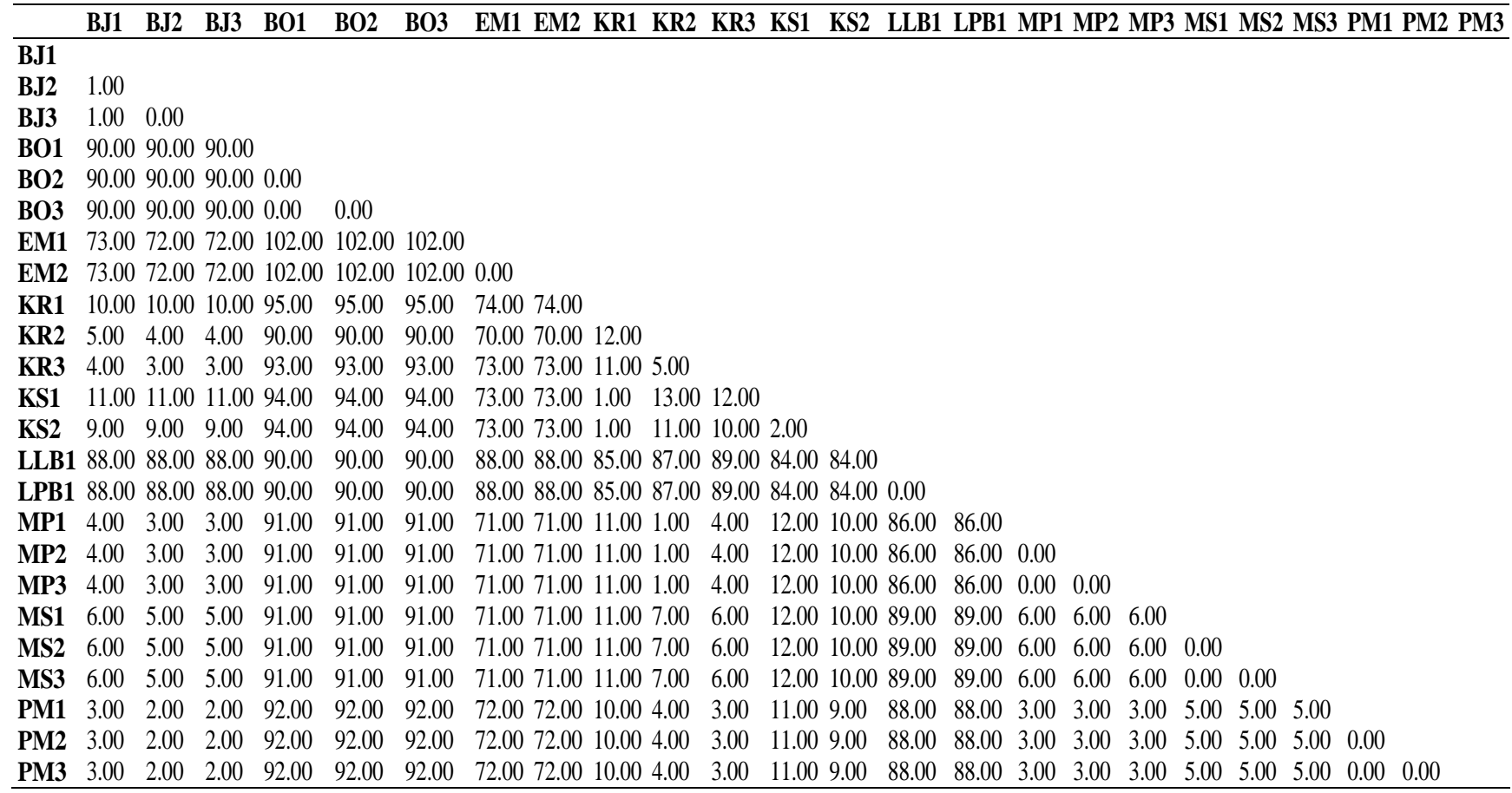

Note: The identity of the samples shown in Table 1

Table 5. Genetic distances of indigenous catfish from different regions of Indonesia

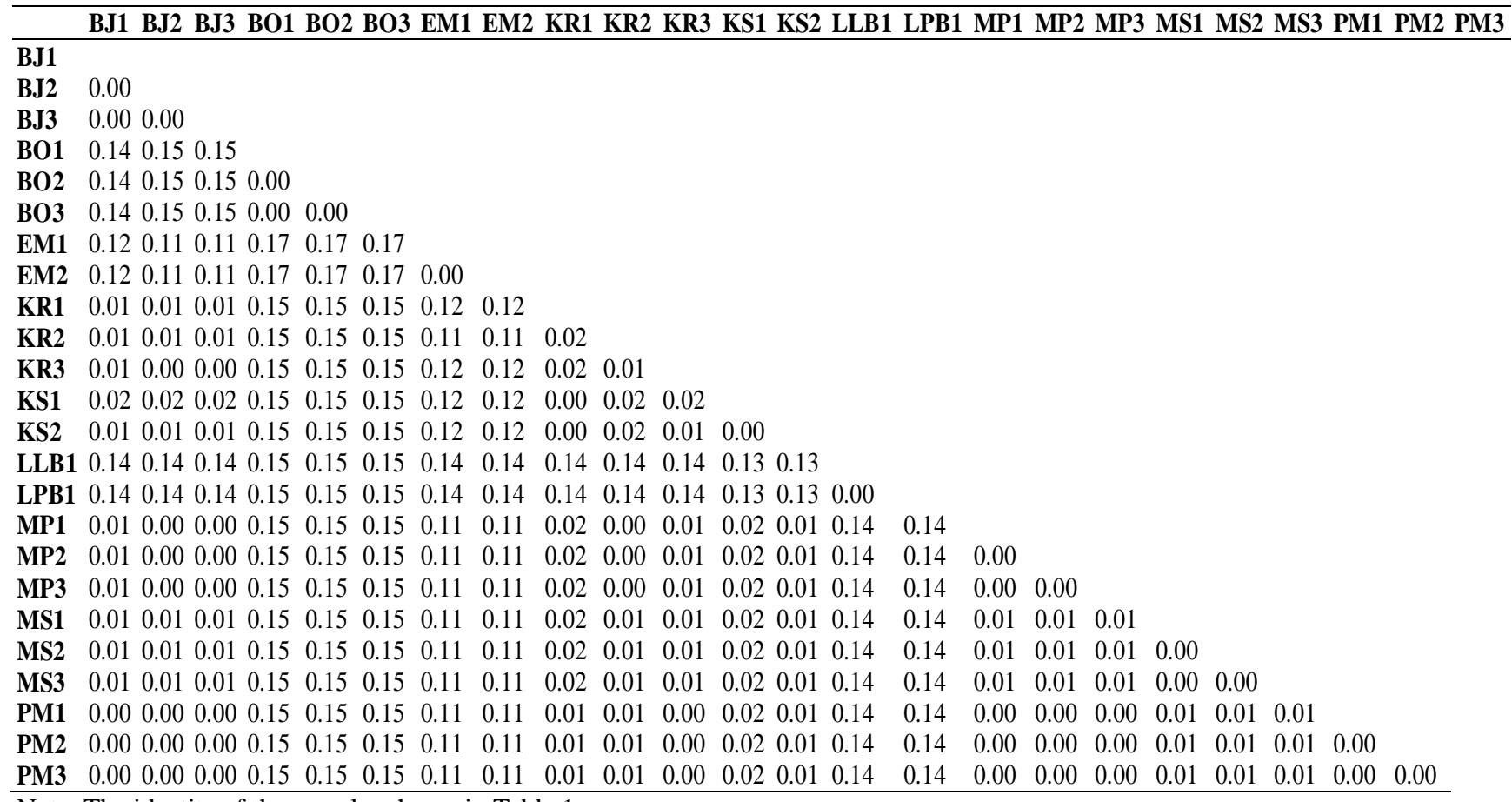

Note: The identity of the samples shown in Table 1 


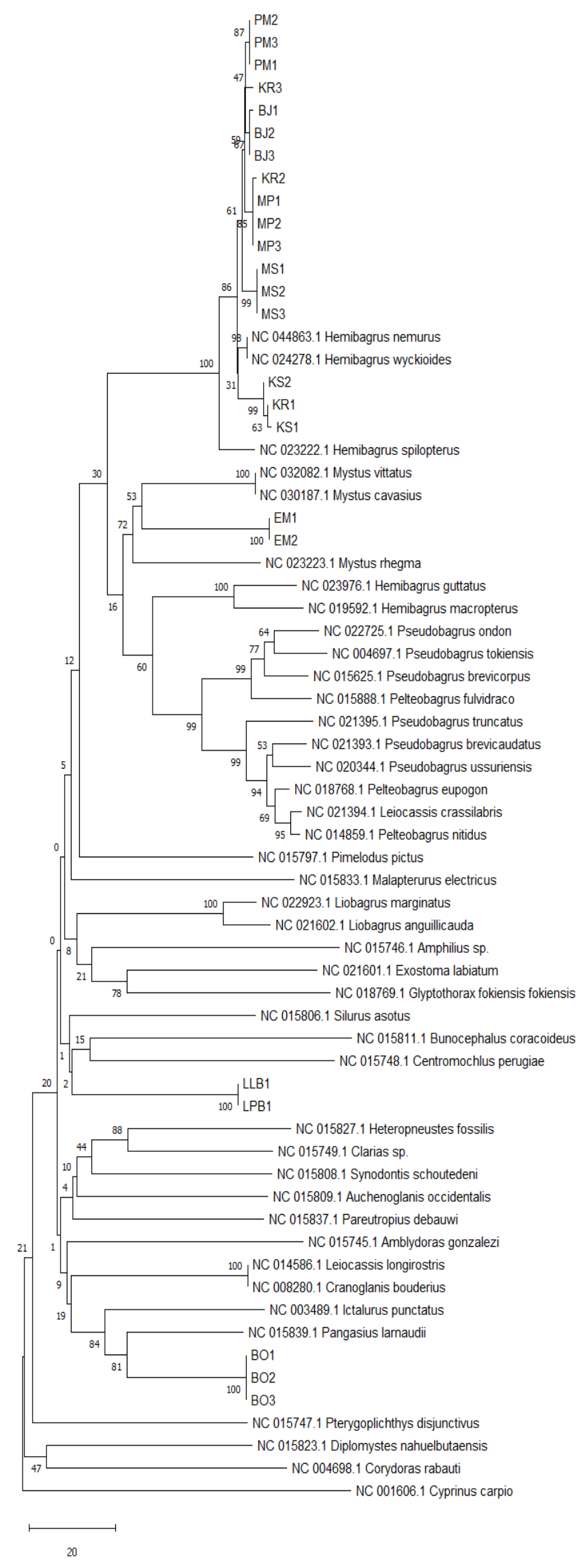

Figure 2. Phylogram of Indonesian catfish based on the Cytochrome Oxidase Subunit II nucleotide sequence
The analysis of the phylogenetic tree based on amino acid sequence shown in Figure 3. Based on amino acid sequences, the Indonesian catfish samples were classified into four monophyletic groups. Samples MS2, MS3, MS1, KR3, KR2, PM3, PM2, PM1, MP1, MP3, MP3, BJ3, BJ2 and samples KR1, KS1, KS2 were together with Hemibagrus nemurus (NC_044863.1) and Hemibagrus wyckioides (NC_024278.1). Samples EM1 and EM2 were clustered with Mystus_vittatus (NC_032082.1), Mystus cavasius (NC_030187.1), and Mystus rhegma (NC_023223.1). Samples LLB1 and LPB1 were in the same clade with Auchenoglanis occidentalis (NC_015809.1), Leiocassis longirostris (NC_014586.1), and Cranoglanis bouderius (NC_008280.1). Meanwhile, samples BO1, BO2, BO3 were grouped with Pangasius_larnaudii (NC_015839.1).

Based on the phylogram, samples PM1, PM2, PM3, KR1, BJ1, BJ2, BJ3, KR2, MP1, MP2, MP3, MS1, MS2, MS3 and KS2, KR1, KS1 were in the same clade with Hemibagrus sp. The species Hemibagrus nemurus has been reported as the species that originated from Southeast Asian (Dodson et al. 1995; Dodson 1999). It makes sense that the species from the river of varied regions of Indonesia were Hemibagrus sp that belong to Bagridae family. Samples from the same Province PM1, PM2, PM3 from Progo River, Magelang, Central Java and samples EM1 and EM2 from Elo River, Magelang, Central Java clustered in two different clades. Sample EM1 and EM2 were in the same group with Mystus vittatus and Mystus cavasius while samples from Progo River identified as Hemibagrus sp. The two different groups however still in same family of Bagridae. Interestingly, the samples from different islands encoded KS1, KS2 from Kapuas River, Sintang, West Kalimantan and KR1 from Kampar River, Pekanbaru, Riau, Sumatera showed close relationship and clustered in the same branch of phylogeny. These findings showed that geographical aspect influenced the genetic diversity but it is possible that species from different islands may have close genetic relation and the samples taken from the same regions can also be a different species but classified in the same family. These results are in line with previous study which reported that genetic diversity in fishes can be influenced by habitat type and environmental factors including their geographical differences (Nicol et al. 2017; Martinez et al. 2018). Further research regarding the effect of geographic location differences on the genetic diversity of catfish is needed.

The samples encoded BO1, BO2, BO3 from Bengawan Solo River, Bojonegoro, East Java were clustered in the same group with Pangasius larnaudii. which belong to Pangasiidae family. The phylogenetic analysis of samples LB1 and LPB1 was not clearly defined using the comparative species then we did separate phylogenetic analysis for those samples with the addition of sea catfishes species from the Ariidae family (Denadai et al. 2012). The results showed that samples LLB1 and LPB1 were clustered in the same groups with Arius arius (NC_036673.1) and Arius maculatus (NC_045222.1) as shown in Figure 4. This described that species from river and coastal from Indonesia belong to different families. 


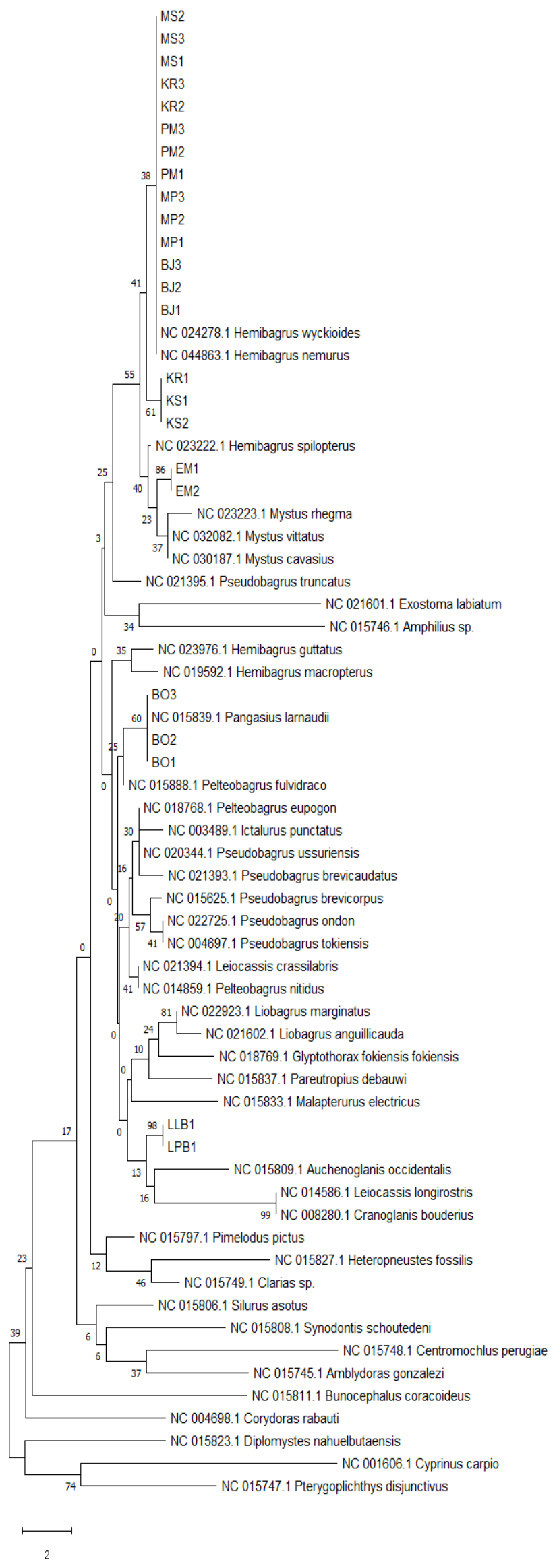

Figure 3. Phylogram of Indonesian catfish based on the Cytochrome Oxidase Subunit II amino acid sequences

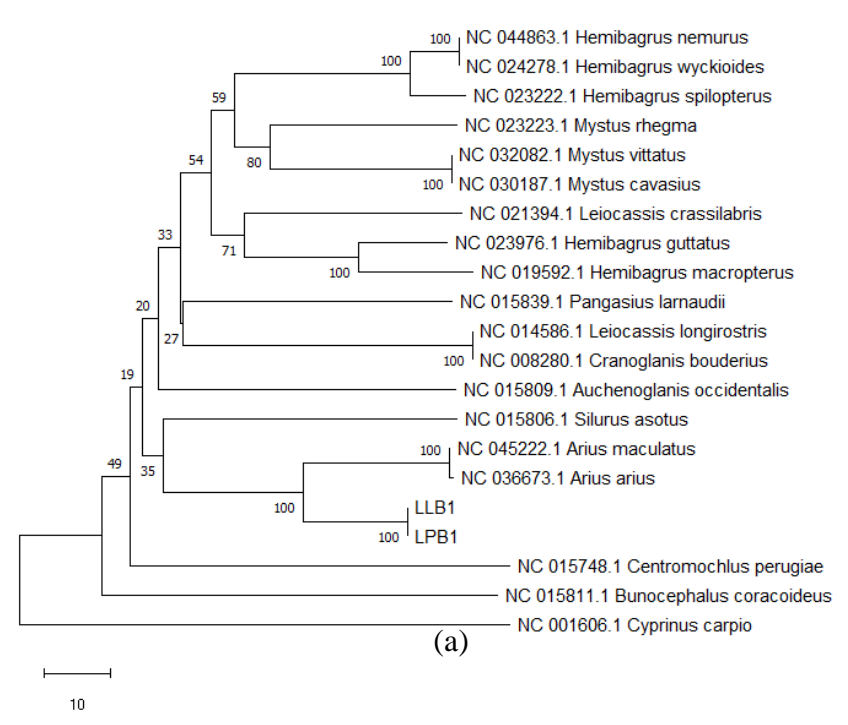

A

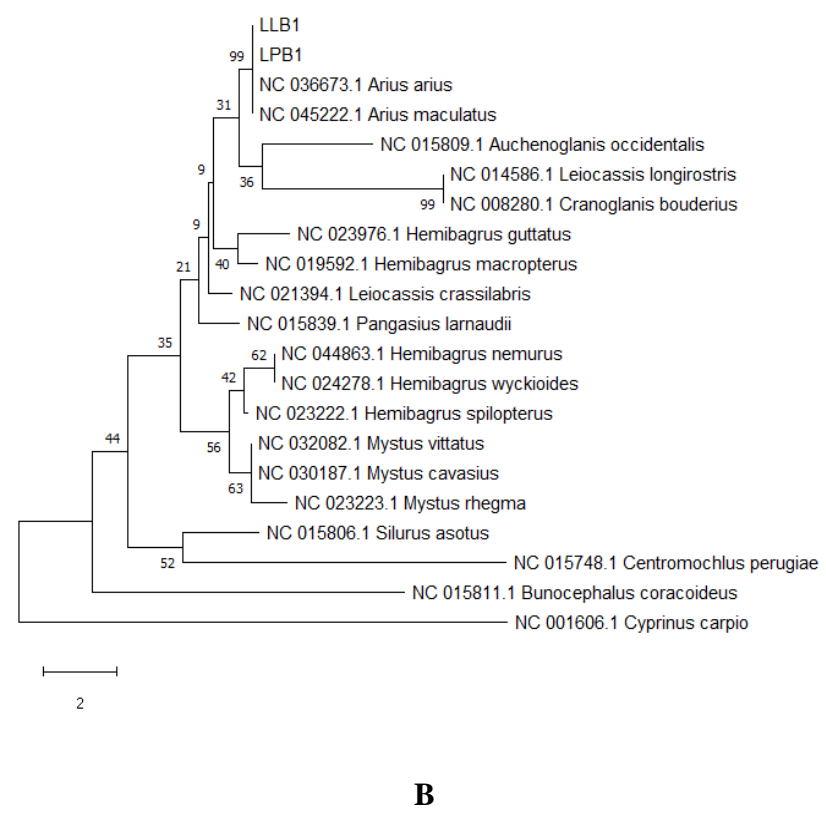

Figure 4. Phylogram of samples LLB1 LPB1 on the Cytochrome Oxidase Subunit II nucleotide (A) and amino acid sequences (B)

This study concludes that there is genetic diversity of the indigenous catfish from Indonesia based on mitochondrial cytochrome oxidase subunit II gene. Samples from the Central Java, Sumatra, and Kalimantan river belonged to Bagridae family and consist of two different species Hemibagrus sp. and Mystus sp while samples from East Java belonged to Pangasiidae family, and sample is taken from coastal belonged to Ariidae family. Besides, we can also conclude that the COII gene especially its amino acid polymorphic site can be used to distinguish catfishes (order Siluriformes) in Indonesia. 


\section{ACKNOWLEDGEMENTS}

The study was financially supported by Faculty of Veterinary Medicine, Universitas Gadjah Mada, Yogyakarta, Indonesia through the Research Assistance Program 2020 (Grant number: 1789/UN.1/FKH/HK4/2020). The authors would like to thank all the staff and students at the Department of Biochemistry and Molecular Biology, Faculty of Veterinary Medicine, Universitas Gadjah Mada.

\section{REFERENCES}

Arce M, Reis RE, Geneva AJ, Pérez MHS. 2013. Molecular phylogeny of thorny catfishes (Siluriformes: Doradidae). Mol Phylogenet Evol 67 560-577. DOI: 10.1016/j.ympev.2013.02.021

Armbruster JW. 2004. Phylogenetic relationships of the suckermouth armoured catfishes (Loricariidae) with emphasis on the Hypostominae and the Ancistrinae. Zool J Linnean Soc 141: 1-80. DOI: $10.1111 /$ j.1096-3642.2004.00109.x

Buj I, Šanda R, Marčić Z, Ćaleta M, Mrakovčić, M. 2014. Combining morphology and genetics in resolving taxonomy-a systematic revision of spined loaches (Genus Cobitis; Cypriniformes, Actinopterygii) in the Adriatic watershed. PLoS One 9 (6): e99833. DOI 10.1371/journal.pone.0099833

Denadai MR, Bessa E, Santos FB, Fernandez WS, Santos FMC, Feijo MM, Arcuri ACD, Turra A. 2012. Life history of three catfish species (Siluriformes: Ariidae) from Southeastern Brazil. Biota Neotrop 12 (4): $74-83$.

Dodson JJ, Colombani F, Ng PKL. 1995. Phylogeographic structure in mitochondrial DNA of a South-East Asian freshwater fish, Hemibagrus nemurus (Siluroidei; Bagridae) and Pleistocene sea-level changes on the Sunda shelf. Mol Ecol 4 (3): 331-346. DOI 10.1111/j.1365-294X.1995.tb00226.x

Dodson JJ. 1999. Morphological and genetic description of a new species of catfish, Hemibagrus chrysops, from Sarawak, East Malaysia, with an assessment of phylogenetic relationships (Teleostei: Bagridae). Raffles. Bull Zool 47 (1): 45-58.

Ferraris CJ. 2007. Checklist of catfishes, recent and fossil (Osteichthyes Siluriformes), and catalog of Siluriform primary types. Zootaxa 1418 (1): 1-628.

Jin Y, Liu S, Yuan Z, Yang Y, Tan S, Liu Z. 2016. Genomics in Aquaculture Catfish Genomic Studies: Progress and Perspectives. Elsevier Inc. DOI: 10.1016/B978-0-12-801418-9/00004-4

Kappas I, Vittas, Pantzartzi CN, Drosopoulou E, Scouras ZG. 2016. A time-calibrated mitogenome phylogeny of catfish (Teleostei
Siluriformes). PLoS ONE 11 (12): 1-16. DOI: 10.1371/journal.pone.0166988

Kawiji, Anam C, Parnanto N, Ariyoga UN. 2020. Catfish (Pangasius Sp.) as a protein source in increasing instant baby food (MpasI) quality with freeze-drying method. AIP Conference Proceedings 2219 (May): 3-8.

Kirk H, Freeland JR. 2011. Applications and implications of neutral versus non-neutral markers in molecular ecology. Int J Mol Sci 12 (6): 3966-3988. DOI: 10.3390/ijms12063966

Kumar S, Stecher G. Li M, Knyaz C, Tamura, K. 2018. MEGA X: Molecular evolutionary genetics analysis across computing platforms. Mol Biol Evol 35 (6): 1547-1549. DOI: 10.1093/molbev/msy096

Liu Z. 2008. Catfish. In: Thomas KD, Chittaranjan, K. (Eds.), Genome Mapping and Genomics in Fishes and Aquatic Animals. Berlin Heidelberg.

Liu Z. 2011. Development of genomic resources in support of sequencing, assembly, and annotation of the catfish genome. Comp Biochem Physiol Part D Genomics Proteomics 6 (1): 11-7. DOI: 10.1016/j.cbd.2010.03.001

Martinez AS, Willoughby JR, Christie MR. 2018. Genetic diversity in fishes is influenced by habitat type and life-history variation. Ecol Evol 8: 12022-12031. DOI: 10.1002/ece3.4661

Megarani DV, Nugroho HA, Andarini ZP, Surbakti YDRBR, Widayanti R. 2020. Genetic characterization and phylogenetic study of Indonesian indigenous catfish based on mitochondrial cytochrome B gene. Vet World 13 (1): 96-103. DOI: 10.14202/vetworld.2020.96103

Mesomya W, Cuptapun Y, Jittanoonta P, Hengsawadi D, Boonsivut S, Huttayanon P, Sriwatana W. 2002. Nutritional evaluations of green catfish, Mystus nemurus. J Nat Sci 36 (1): 69-74.

$\mathrm{Ng} \mathrm{HH}$, Kottelat M. 2013. Revision of the Asian catfish Genus Hemibagrus Bleeker, 1862 (Teleostei: Siluriformes: Bagridae). Raffles. Bull Zool 61 (1): 205-291.

Nicol E, Stevens JR, Jobling S. 2017. Riverine fish diversity varies according to geographical isolation and land use modification. Ecol. Evol 7: 7872-7883.

Syaifudin M, Jubaedah D, Muslim M, Daryani A. 2018. DNA authentication of Asian redtail catfish Hemibagrus nemurus from Musi and Penukal river, South Sumatra Indonesia. Genet Aquat Organ 1 (1): 43-48.

Widayanti R, Haryanto A, Artama WT, Pakpahan S. 2019. Genetic variation and phylogenetic analysis of Indonesian indigenous catfish based on mitochondrial cytochrome oxidase subunit III gene. Vet World 12 (6): 896-900. DOI: 10.14202/vetworld.2019.896-900

Wilson DE, Reeder DM. 2005. Mammal Species of the World: A Taxonomic and Geographic Reference, third ed. Johns Hopkins University Press, Baltimore, Maryland. 